Research Paper

\title{
Inhibition of MAPKs, Myc/Max, NFKB, and Hypoxia Pathways by Phyllanthus Prevents Proliferation, Metastasis and Angiogenesis in Human Melanoma (MeWo) Cancer Cell Line
}

\author{
Yin-Quan Tang1, Indu Bala Jaganath², Rishya Manikam ${ }^{3}$ and Shamala Devi Sekaran ${ }^{\circledR}$ \\ 1. Department of Medical Microbiology, Faculty of Medicine, University of Malaya, Kuala Lumpur, Malaysia \\ 2. Biotechnology Centre, Malaysia Agricultural Research and Development Institute (MARDI), Serdang, Malaysia. \\ 3. Department of Trauma and Emergency Medicine, Faculty of Medicine, University of Malaya, Kuala Lumpur, Malaysia. \\ $\square$ Corresponding author: Department of Medical Microbiology, Faculty of Medicine, University of Malaya, Kuala Lumpur; Tel: \\ +6079675759, Fax: +60379676672. E-mail address: shamalamy@yahoo.com.
}

(C) Ivyspring International Publisher. This is an open-access article distributed under the terms of the Creative Commons License (http://creativecommons.org/ licenses/by-nc-nd/3.0/). Reproduction is permitted for personal, noncommercial use, provided that the article is in whole, unmodified, and properly cited.

Received: 2013.09.18; Accepted: 2014.02.18; Published: 2014.04.07

\begin{abstract}
Background: Melanoma is the most fatal form of skin cancer. Different signalling pathways and proteins will be differentially expressed to pace with the tumour growth. Thus, these signalling molecules and proteins are become potential targets to halt the progression of cancer. The present works were attempted to investigate the underlying molecular mechanisms of anticancer effects of Phyllanthus (P.amarus, P.niruri, P.urinaria and P.watsonii) on skin melanoma, MeWo cells. Methods: The ten cancer-related pathways reporter array was performed by transfection of plasmid construct of transcription factor-responsive reporter of each pathway in MeWo cells. The affected pathways in MeWo cells after treatment of Phyllanthus extracts were determined using luciferase assay. Western blot, 2D gel electrophoresis and mass spectrometry analysis were performed to identity and confirm the affected proteins and signalling molecules in treated cells. Results: The ten-pathway reporter array revealed five different cancer-related signalling pathways were altered by Phyllanthus species in MeWo cells; NFKB, Myc/Max, Hypoxia, MAPK/ERK and MAPK/JNK $(p<0.05)$. Western blot revealed that their intracellular signalling molecules including pan-Ras, c-Raf, RSK, phospho-ElkI, c-myc, Akt, HIF-Ia, Bcl-2, and VEGF were down-regulated with concurrent of up-regulation; Bax, phospho-JNK-I/2 and phospho-GSK3 $\beta$, in MeWo cells upon Phyllanthus treatment $(\mathrm{p}<0.05)$. Proteomics-based approach was performed and MS/MS results revealed that 52 differential expressed proteins were identified $(p<0.05)$ and involved in tumour growth, metastasis, apoptosis, glycogenesis and glycolysis, angiogenesis, protein synthesis and energy metabolism. Conclusion: This study provides insight into the regulation on multiple survival signalling pathways by Phyllanthus in melanoma and might be a therapeutic target for cancer treatment.
\end{abstract}

Key words: Phyllanthus, apoptosis, signaling, melanoma.

\section{Introduction}

Malignant melanoma is the most aggressive and life-threatening skin cancer with increasing incidences over the past decades. This disease is prevalent in faired-skin populations, and is easy to detect due to its abnormal colour, size and pigmentation. Despite ac- counting for only $4 \%$ of all skin cancers, melanoma confers $80 \%$ of skin cancer induced death [1]. Although, melanoma has high recovery rates if detected early, it has a high tendency of metastasizing, dropping the 5-year survival rate less than 5\% [2]. The 
underlying cause of melanoma progression and metastasis is poorly understood, hence limiting the effectiveness of current treatments and contributing to increased cases of recurrence or refractory melanoma. Thus, it is vital that future anticancer agents can combat both local and metastatic melanoma.

Many vital biological processes are tightly regulated by complex signalling networks and signal transduction occurs when an external stimuli (e.g. stress, UV) initiate changes in a cell upon binding of ligand to surface receptor. This causes conformational changes to the intracellular signalling molecules, which in turn elicit cellular responses. Disruption of these pathways or intracellular communication can result in various diseases, including cancer [3, 4]. Thus, signalling molecules have become potential targets to halt cancer progression by inducing apoptosis and/or inhibiting tumour metastasis and angiogenesis.

The mitogen activated protein kinase family members (MAPKs) are highly expressed in melanoma and it is believed this pathway mediates melanoma metastasis by inducing proteolytic enzymes (e.g. MMP) activation that leads to degradation of basement membrane, and also by regulating genes involved in cell migration, cell survival and growth [5]. MAPK pathway also has been found in other cancers such as breast, colon, prostate and lung, suggesting a role for MAPK pathway in tumour progression and metastasis [6-9]. Disrupting this pathway may halt cancer progression by inhibition of tumour angiogenesis, proliferation, invasion and metastasis. In melanoma, several other pathways have also been shown to be highly expressed including PI3K/Akt and $\mathrm{NFKB}_{\mathrm{B}}$ signal transduction pathways and have been associated with tumour development and progression [10-12].

During tumour metastasis, high oxygen delivery and consumption requires activation of hypoxia-inducible factors (HIFs), which induce transcription of growth-related genes such as vascular endothelial growth factor (VEGF). The activation of VEGF can stimulate tumour angiogenesis and thereby increase the oxygen delivery [13]. These changes in hypoxic cancer cells allow them to acquire invasive and metastatic properties as well as to develop resistance to chemotherapy [14].

The pharmacological effects of Phyllanthus, a widely distributed medicinal plant, are many including antiviral [15], anti-bacteria [16] and anti-hepatotoxic [17] as well as with anticancer properties [18]. Previously, we reported four species of Phyllanthus to possess anti-proliferative effect and apoptosis inducing capabilities in melanoma cell [19]. Currently, to understand the mechanism behind the anticancer properties of Phyllanthus on melanoma cells, we investigated the changes to intracellular signalling network upon treatment. At the same time, we also seek to identify potential new targets for therapeutic intervention in skin melanoma.

\section{Materials and Methods}

\section{Preparation of Phyllanthus Extracts}

P.amarus, P.niruri, P.urinaria, and P.watsonii were the four different species of Phyllanthus plant used in this study. Both aqueous and methanolic extracts of each Phyllanthus were prepared as described previously by Tang et al. [19]. Briefly, plant samples were freshly harvested, washed, and freeze dried. For aqueous extract preparation, ultra-pure water was used to soak the dried plant samples and absolute methanol was used to prepare the methanolic extract. The samples then were homogenized with extraction buffer and the supernatant was collected after three rounds of extraction. Lyophilized forms of aqueous and methanolic extracts were obtained after evaporation and stored at $-20^{\circ} \mathrm{C}$ prior to experiments.

\section{Chemicals and antibodies}

EMEM (Eagle's minimum essential medium) was purchased from Sigma (St. Louis, MO). Foetal bovine serum (FBS) was obtained from Gibco. Antibodies; pan-Ras, c-Raf, RSK, phosopho-Elk1, c-Jun, phospho-JNK-1/2, c-myc, HIF-1a, Bcl-2, Bax, NFkB p50 and p52, VEGF, phospho-GSK3 $\beta$, phospho-p38 MAPK and p53 were obtained from MERCK, San Diego, USA. While urea, CHAPS, DTT IPG buffer ( $\mathrm{pH}$ 3-11NL), SDS, bromophenol blue Tris, glycine, acrylamide, bis-acrylamide were purchased from GE Healthcare.

\section{Cell culture}

Skin melanoma MeWo (HTB-65) cell line was purchased from American Type Culture Collection (Rockville, MD) and cultured with EMEM. This medium was supplemented with $10 \%$ heat-inactivated foetal bovine serum (FBS, Gibco). Cells were maintained in culture at $37^{\circ} \mathrm{C}$ with $5 \% \mathrm{CO}_{2}$ and $95 \%$ humidity. Cells were harvested using $0.25 \%$ trypsin (Hyclone) when they reach $70-80 \%$ confluency in culture flasks. Cells undergoing exponential growth were used throughout the experiments.

\section{Dual luciferase pathway reporter transient transfection}

Ten different cancer-related pathways analysis was performed using the Cignal Finder 10-Pathway Reporter Arrays (SA Biosciences, Fredrick, MD). Optimization of the conditions, including amount and incubation time of plasmid construct of transcription 
factor-responsive reporter of each pathway into the cells, was performed to ensure highly transfection efficiency and inhibit transformation. After optimization, MeWo cells were seeded into a 96-well white plate and incubated overnight at $37^{\circ} \mathrm{C}$. Transient transfection was conducted by adding plasmid construct of transcription factor-responsive reporter of each pathway and controls to cells and incubated overnight in a $37^{\circ} \mathrm{C}$ incubator. Then, cells were treated with Phyllanthus extracts at their respective $\mathrm{IC}_{50}$ values (Table 1) and further incubated for 48 hours. Each transfection condition was carried in triplicates. Each of the pathways/reporters consist an inducible transcription factor responsive firefly luciferase reporter and constitutively expressing Renilla construct. Renilla construct is to act as an internal control for normalizing transfection efficiencies and monitor cell viability. After $48 \mathrm{~h}$ of Phyllanthus treatment, the changes in expression of each pathway in cells were determined by measuring the generated firefly and Renilla luminescent signals using the Dual-Glo Luciferase Assay system (Promega, Madison, WI) on the Glomax machine (Promega, USA). The relative luciferase units were determined by dividing the firefly to Renilla luciferase activity ratio.

Table I. Treatment of MeWo cells at different $I_{50}$ values of Phyllanthus extracts.

\begin{tabular}{lll}
\hline & & $\mathrm{IC}_{50 \pm} \mathrm{SEM}(\mu \mathrm{g} / \mathrm{ml})$ \\
\hline $\begin{array}{l}\text { Phyllanthus species } \\
\text { P.amarus }(P A)\end{array}$ & Extracts & $\mathrm{MeWo}$ \\
& Aqueous $\left(\mathrm{H}_{2} 0\right)$ & $193.3 \pm 1.3$ \\
P.niruri $(\mathrm{PN})$ & Methanolic $(\mathrm{MeOH})$ & $133.3 \pm 2.9$ \\
& Aqueous $\left(\mathrm{H}_{2} 0\right)$ & $260.0 \pm 2.4$ \\
P.urinaria $(\mathrm{PU})$ & Methanolic $(\mathrm{MeOH})$ & $153.3 \pm 2.6$ \\
& Aqueous $\left(\mathrm{H}_{2} 0\right)$ & $193.3 \pm 1.1$ \\
P.watsonii $(\mathrm{PW})$ & Methanolic $(\mathrm{MeOH})$ & $56.2 \pm 3.2$ \\
& Aqueous $\left(\mathrm{H}_{2} 0\right)$ & $160.0 \pm 3.2$ \\
& Methanolic $(\mathrm{MeOH})$ & $100.7 \pm 2.0$ \\
\hline
\end{tabular}

\section{Western Blot analysis}

The intracellular signalling molecules in MAPK (pan-Ras, c-Raf, phospho-Elk1，RSK, c-Jun, phospho-JNK-1/2, Akt and phospho-p38 MAPK), Myc/Max (c-myc) and Hypoxia (c-myc, HIF-1a, VEGF and GSK3 $\beta$ ), NFKB (p50 and p52), as well as p53 (p53, Bcl-2, Bax) pathways were chosen for western blot analysis. Beta actin was used as a loading control. Briefly, protein lysates from Phyllanthus-treated (Table 1) and untreated groups after 48 hours of treatment were resolved on 12\% SDS-PAGE gels. After electrophoresis, proteins were transferred onto nitrocellulose membranes, followed by blocking and incubation with primary antibodies overnight at $4^{\circ} \mathrm{C}$. Subsequently, the membranes were incubated with appropriate secondary antibodies (horseradish-conjugated goat anti-mouse or anti-goat $\operatorname{IgG}$ ) for $1 \mathrm{~h}$. Open-source software, ImageJ was used to measure band intensities. The percentage of protein expression was calculated by dividing the band intensity of treated group with the untreated group.

\section{Two-Dimensional Gel Electrophoresis}

A total of $500 \mathrm{mg}$ protein was subjected to $2 \mathrm{D}$ gel electrophoresis according to the manufacturer's instructions (GE Healthcare). Briefly, total protein was extracted from cells (untreated and treated groups) after 48 hours of treatment (Table 1), by incubation with cold lysis buffer on ice for 30 minutes. The protein pellets were re-solubilized in rehydration solution (8 M urea, 2\% CHAPS, $40 \mathrm{mM}$ DTT, 0.5\% IPG buffer pH3-11NL, bromophenol blue). A total of $500 \mathrm{mg}$ protein rehydrated into $13 \mathrm{~cm}$ immobilized $\mathrm{pH}$ gradient (IPG) strips (pH 3-11 nonlinear) (GE Healthcare) overnight. The first dimension was run on the IPGphor III machine (GE Healthcare) at $20^{\circ} \mathrm{C}$ with the following settings: step 1 at $500 \mathrm{~V}$ for $1 \mathrm{~h}$; step 2 at $500-1000 \mathrm{~V}$ for $1 \mathrm{~h}$; step 3 at $1000-8000 \mathrm{~V}$ for $2.5 \mathrm{~h}$, and step 4 at $8000 \mathrm{~V}$ for $0.5 \mathrm{~h}$. Upon completion of first dimensional separation, the strip was equilibrated as following; first reduction with $64.8 \mathrm{mM}$ of dithiothreitol-SDS equilibration buffer $(50 \mathrm{mM}$ Tris- $\mathrm{HCl}$ [pH 8.8], $6 \mathrm{M}$ urea, 30\% glycerol, $2 \%$ SDS, $0.002 \%$ bromophenol blue) for 15 minutes, followed by alkylation with $135.2 \mathrm{mM}$ of iodoacetamide-SDS equilibration buffer for another 15 minutes. The second dimension electrophoresis was performed by electrophoresing the samples in $12.5 \%$ SDS acrylamide gels by using the SE600 Ruby system (GE Healthcare) at $25^{\circ} \mathrm{C}$ in an electrode buffer $(25 \mathrm{mM}$ Tris, $192 \mathrm{mM}$ glycine, and $0.1 \%$ [wt/vol] SDS) with the following settings: step 1 at $100 \mathrm{~V} /$ gel for 45 minutes; step 2 at $300 \mathrm{~V} /$ gel until the run is completed. After electrophoresis, the gels were fixed with destaining solution for 30 minutes, followed by staining with hot Coomasie blue for 30 minutes. Lastly, the gels were scanned using Ettan DIGE Imager (GE Healthcare). Gel images were analyzed using PDQuest 2-D Analysis Software (Bio-Rad, USA) and only protein spots which showed significant differences (more than 1.0 fold) were selected for mass spectrometry analysis.

\section{Protein Digestion, Desalting and MALDI-TOF/TOF Analysis}

The significant differential expressed protein spots were excised from the polyacrylamide gels and kept in sterile $1.5 \mathrm{ml}$ eppendorf tubes. Excised spots (gel plugs) were washed with destaining solution (50 $\mathrm{mM} \mathrm{NH}_{4} \mathrm{HCO}_{3}$ ) until the gel plugs were clear. The gel plugs were then incubated with reducing solution 
(100 mM NH $\mathrm{NHCO}_{3}$ containing $10 \mathrm{mM}$ DTT) for 30 min at $60^{\circ} \mathrm{C}$. The gel plugs were alkylated with 100 $\mathrm{mM} \mathrm{NH} \mathrm{HCO}_{3}$ containing $55 \mathrm{mM}$ of IAA for $20 \mathrm{~min}$ in the dark and followed with three times washed with $50 \%$ acetone in $100 \mathrm{mM} \mathrm{NH} \mathrm{HCO}_{3}$ for $20 \mathrm{~min}$ each. The gel plugs were then rehydrated with $100 \%$ ACN. In-gel digestion step, trypsin gold (Promega, Mass Spectrometry Grade) was used and added into gel plug and incubated overnight at $37^{\circ} \mathrm{C}$. Proteins were extracted from gel plugs and purified by using Ziptip (Ziptip C18, Millipore, Bedford, MA, USA). The eluted proteins were mixed with MATRIX solution and spotted on MALDI plate using dry droplet method and analysed using Ab Sciex Tof/Tof ${ }^{\mathrm{TM}}$ instrument. The generated peptides were blasted with MASCOT Search Algorithm (Version 2.1.0) to identify the possible proteins.

\section{Statistical Analysis}

For all experiments, results were expressed as the mean \pm standard error (SEM) of data obtained from triplicate experiments using SPSS software. The Student's $t$-test was used where values of $\mathrm{p}<0.05$ were considered significant.

\section{Results}

\section{Alteration in expression of several cancer pathways}

Ten cancer-related pathways including Wnt, Notch, p53, TGF- $\beta$, cell cycle/pRB-E2F, NFkB, Myc/Max, Hypoxia, MAPK/ERK and MAPK/JNK pathways were investigated. The differential expression of each of these pathways in treated and un-

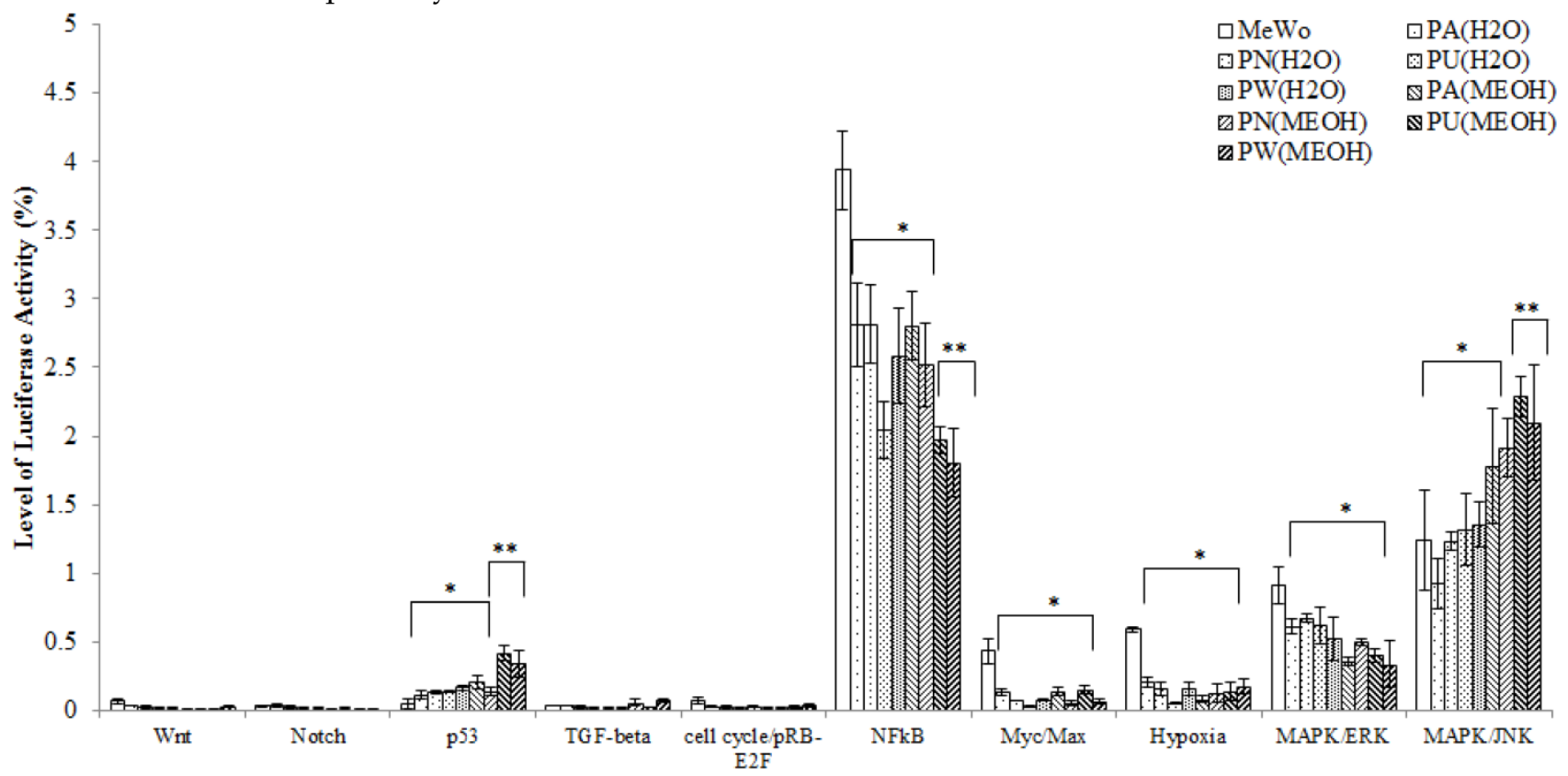

Figure I. The expression of transcription activities in ten-cancer related pathways of untreated and treated MeWo. Four different pathways (NFKB, Myc/Max, Hypoxia, and MAPK/ERK) were significantly down-regulated $(p<0.05)$ and two pathways ( $p 53$ and MAPK/JNK) were up-regulated $(p<0.05)$. Other pathways showed no significant change. Bars show the mean percentage \pm SEM. $* P<0.05$ and $* * P<0.01$ vs control. treated MeWo cells is presented in Figure 1. From Figure 1, it was noted, that in the untreated MeWo cells, six (p53, NFкB, Myc/Max, Hypoxia and MAPK/ERK and MAPK/JNK) investigated pathways were expressed to regulate the cells growth and survival. However, the expressions of NFkB, Myc/Max, hypoxia and MAPK/ERK showed significant down-regulation in Phyllanthus treated MeWo cells $(\mathrm{p}<0.05)$. Contrarily, the expressions of p53 and MAPK/JNK pathways showed significant up-regulation in the treated cells $(p<0.05)$. Other pathways investigated were found to be not significantly affected by Phyllanthus extracts ( $p>0.05)$.

\section{Induction of apoptosis through p53 protein and disruption in anti-apoptotic/pro-apoptotic balance}

As shown in Figure 2, p53 protein was detected at $53 \mathrm{kDa}$ and their expression was significantly up-regulated in Phyllanthus treated MeWo as compared to untreated MeWo cells $(\mathrm{p}<0.05)$. In addition, other apoptosis related proteins including Bcl-2 and Bax were detected at $23 \mathrm{kDa}$ and $26 \mathrm{kDa}$, respectively. The graph shows a significant increase of pro-apoptoic protein, Bax in treated MeWo cells $(p<0.05)$ with a concurrent decrease in anti-apoptotic protein, Bcl-2 $(\mathrm{p}<0.05)$ as compared to untreated MeWo cells. Among the species of Phyllanthus, both aqueous and methanolic extracts of P.watsonnii showed the most significant changes on p53, Bax and $\mathrm{Bcl}$ expression, followed by P.urinaria, P.niruri and P.amarus. 


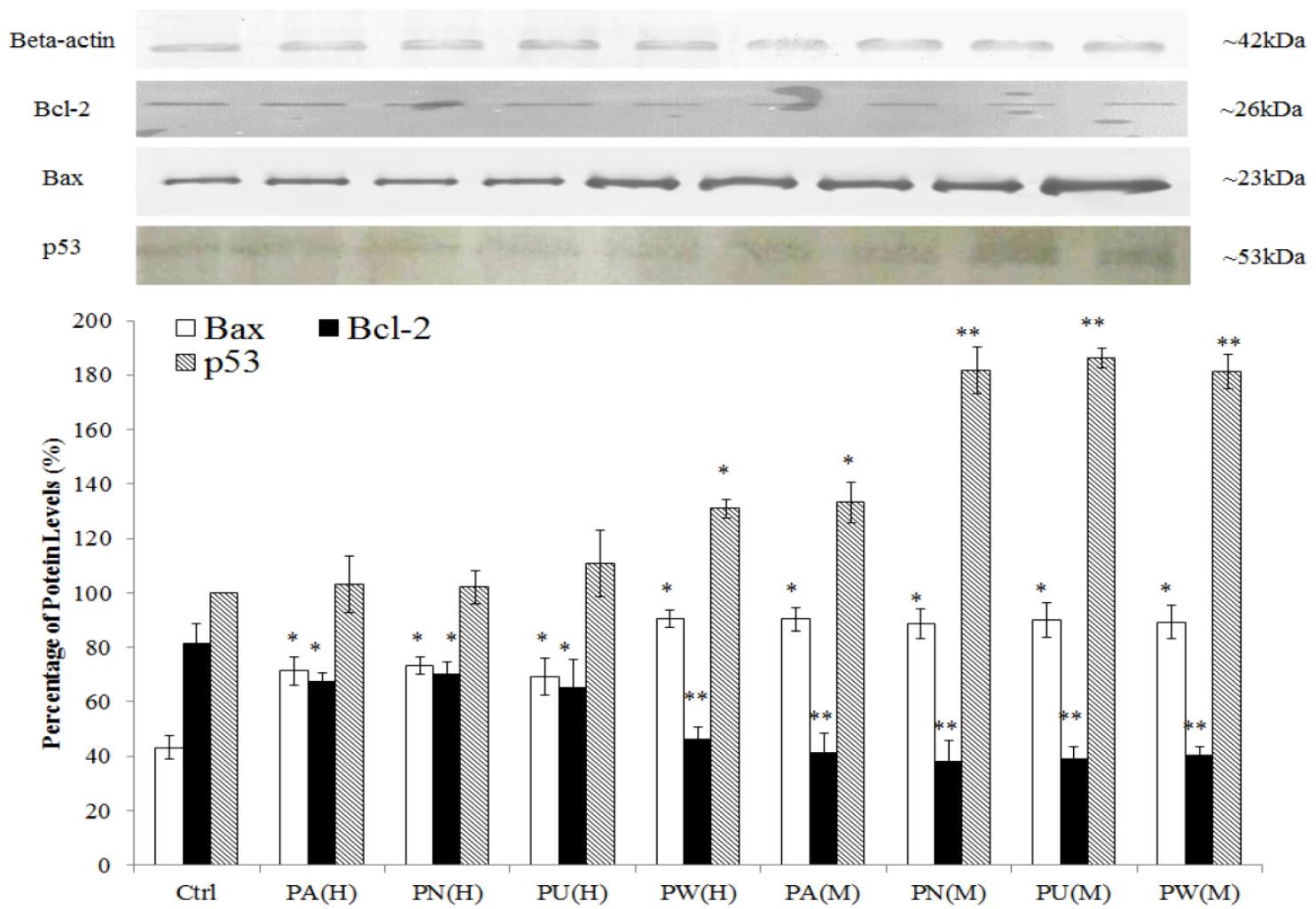

Figure 2. Induction of apoptosis through $\mathrm{p} 53$ pathway and disruption in anti-apoptotic/pro-apoptotic balance. The expression of pro-apoptotic (Bax) was up-regulated and anti-apoptotic ( $\mathrm{Bcl}-2)$ protein was down-regulated in MeWo cells after treatment with Phyllanthus extracts. Bars show the mean percentage \pm SEM. $* P<0.05$ and $* * P<0.01$ vs control.

\section{Phyllanthus alters activities of intracellular signalling molecules in affected pathways}

Three up-stream activator molecules in MAPK pathway; pan-Ras, c-Raf and Akt were highly expressed in untreated MeWo cells (Figure 3). The constitutive activations of these molecules can activate their downstream targets including MAPK/ERK (RSK, phospho-Elk1, c-Jun/AP-1), MAPK/JNK (phospho-JNK-1/2) and p38 (phospho-p38 MAPK). As shown in Figure 3, the expressions of all these intracellular signalling molecules were detected in untreated MeWo cells indicating their involvement in regulating MeWo cells' growth. However, all these intracellular signalling molecules had notable down-regulated expression $(\mathrm{p}<0.05)$ except for phospho-JNK-1/2 protein, which showed a slight increase in expression in treated MeWo cells.

The expression of Myc/Max and hypoxia signalling pathway was detected at increased levels in MeWo cells (Figure 1) with a high percentage down-regulation after treatment with Phyllanthus. In these pathways, four intracellular signalling molecules were detected by western blot; c-myc, HIF-1a, VEGF and phospho-GSK3 $\beta$. As shown in Figure 4, the expression of the c-myc was detected at $65 \mathrm{kDa}$ and its expression was noticed significantly decreased by aqueous- $\quad(\mathrm{p}<0.05)$ and methanolic-Phyllanthus $(p<0.01)$ treated MeWo cells as compared to untreated cells. The downstream targets of c-myc; HIF-1a and VEGF were detected at $120 \mathrm{kDa}$ and $50 \mathrm{kD}$, respectively. Their expressions were significantly down-regulated in treated MeWo cells as compared to untreated cells $(p<0.05)$. A negative regulator of c-myc, phosphorylated glycogen synthase kinase 3-beta (phospho-GSK3 $\beta$ ) was detected at $51 \mathrm{kDa}$ and its expression was significantly up-regulated in treated cells as compared to untreated cells $(p<0.01)$. Two intracellular signalling molecules in NFKB pathway; p50 and p52 were detected at $50 \mathrm{kDa}$ and 52 $\mathrm{kDa}$, respectively (Figure 5). Both NFkB proteins were significantly down-regulated in MeWo cells after treatment with Phyllanthus extracts $(\mathrm{p}<0.05)$.

Among the Phyllanthus species, P.urinaria showed strongest effect on expression of intracellular signalling molecules in affected pathways, followed by P.watsonii, P.amarus and P.niruri for both aqueous and methanolic extracts.

\section{Proteomic profiling of the differentially expressed proteins in Phyllanthus treated MeWo cells}

Differentially expressed proteins in MeWo cells were statistically defined based on two criteria: 1) degree of intensity $>1.0$ fold (Protein scores greater 
than 52 are significant, $\mathrm{p}<0.05$ ) and 2) reoccurrence in the three repeated experiments (Figure 6). According to these criteria, 52 proteins were identified by MS/MS and grouped in four biological processes based on their functions described in UniProtKB/Swiss-Prot protein database (Table 2).

In Group I (cell adhesion, migration, invasion and metastasis), 8 proteins were found to be differentially expressed in treated MeWo cells. Of these, type I cytoskeletal 13 keratin was found to be up-regulated $(p<0.05)$. Its expression was significantly up-regulated about 1.4-1.8 folds higher than untreated cells. The other identified proteins were down-regulated in treated cells; Ephrin-B1, alpha-centractin, bystin, superoxide dismutase, tubulin beta chain, F-actin-capping protein subunit alpha-2 and partitioning defective 3 homolog.

In Group II (proliferation, cell cycle and apoptosis), 21 proteins were significantly down-regulated in MeWo cells after treatment with Phyllanthus extracts. Among these down-regulated proteins, HCLS1-associated protein X-1 and casein kinase II subunit alpha proteins showed the greatest reduction at 1.5-2.3 folds in their expression as compared to untreated cells $(\mathrm{p}<0.05)$.

In Group III (glycogenesis and glycolysis), 5 down-regulated enzymes were detected in treated MeWo cells. These identified enzymes were glucosamine--fructose-6-phosphate aminotransferase, protein phosphatase 1 regulatory subunit 3D, alpha-enolase, pyruvate kinase isozymes M1/M2 and phosphoglycerate kinase 1.

In Group IV (protein synthesis and energy metabolisms), 15 proteins were found to be down-regulated at the range of 1.3-1.9 in Phyllanthus treated MeWo cells as compared to untreated cells. Eight of these proteins; E3 ubiquitin-protein ligase ARIH2 and RNF115, aspartate aminotransferase, 26S protease regulatory subunit 8 , putative elongation factor 1-alpha-like 3, mitochondrial inner membrane organizing system protein 1 (MINOS), zinc finger protein, Sec1 and trimethyllysine dioxygenase, have been known to be involved in regulation of mitochondrial integrity and protein ubiquitination.

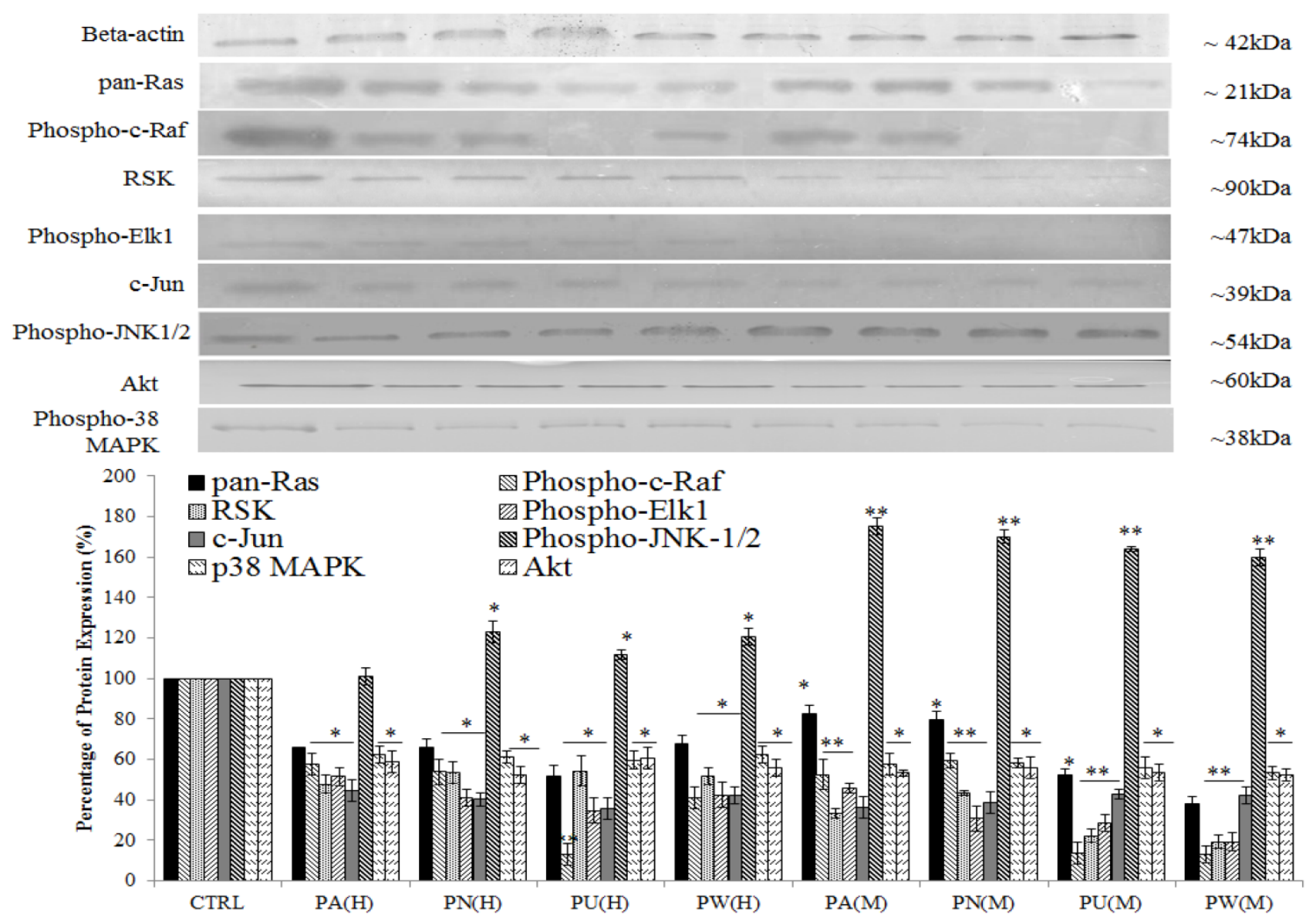

Figure 3. Inhibition of MAPK/ERK and p38 MAPK but activation of MAPK/JNK pathways in MeWo cells. The expressions of Ras, Raf, phospho-ElkI, RSK, phospho-JNK-I/2, c-Jun, phospho-p38 MAPK and Akt in treated MeWo were significantly down-regulated. Bars show the mean percentage \pm SEM. $* P<0.05$ and $* * P<0.01$ vs control. 


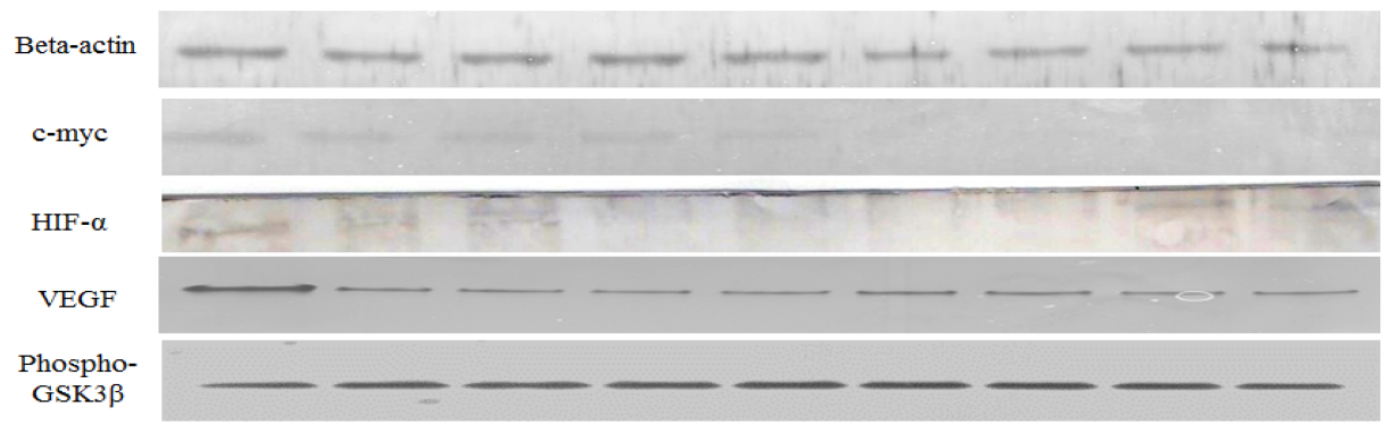

$\sim 42 \mathrm{kDa}$

$\sim 65 \mathrm{kDa}$

$\sim 120 \mathrm{kDa}$

$\sim 42 \mathrm{kDa}$

$\sim 51 \mathrm{kDa}$

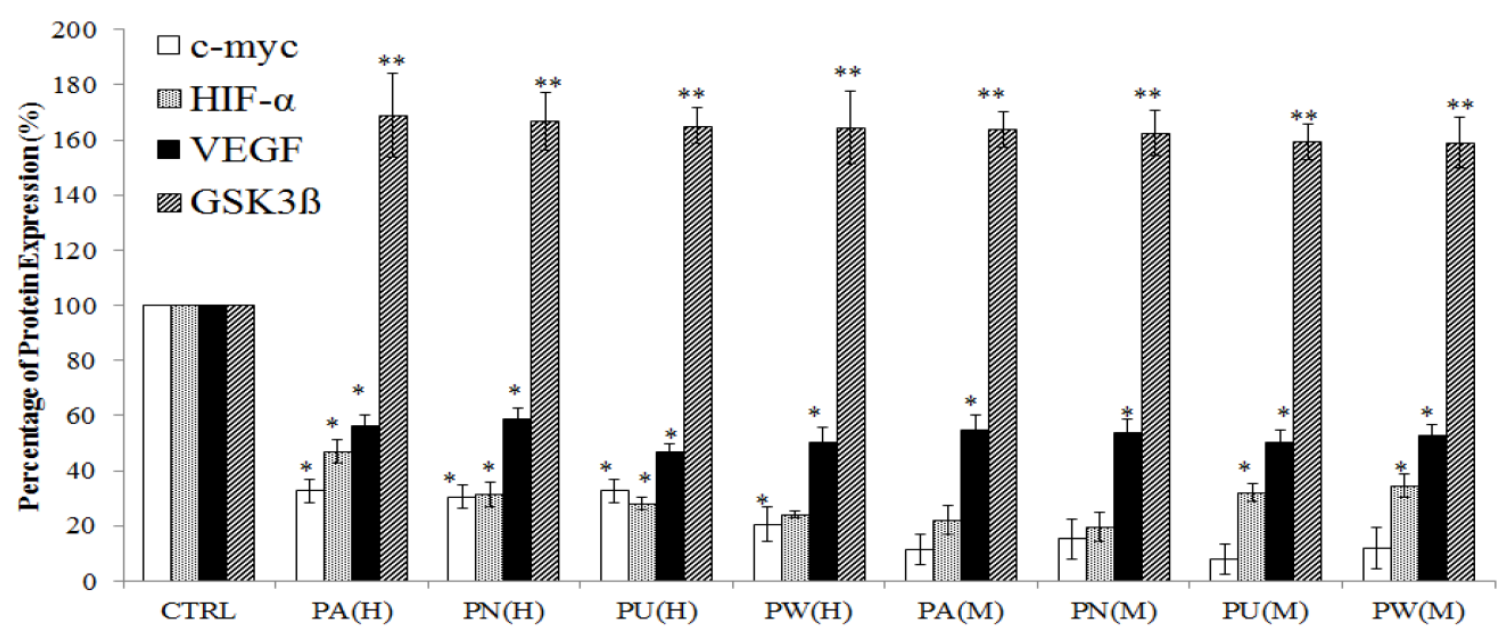

Figure 4. Phyllanthus alters expression in c-Myc and Hypoxia pathways of MeWo cells. The expressions of c-Myc, HIF-Ia and VEGF were significantly down-regulated in conjunction with up-regulation of phospho-GSK3 $\beta$. Bars show the mean percentage \pm SEM. $* P<0.05$ and $* * P<0.01$ vs control.

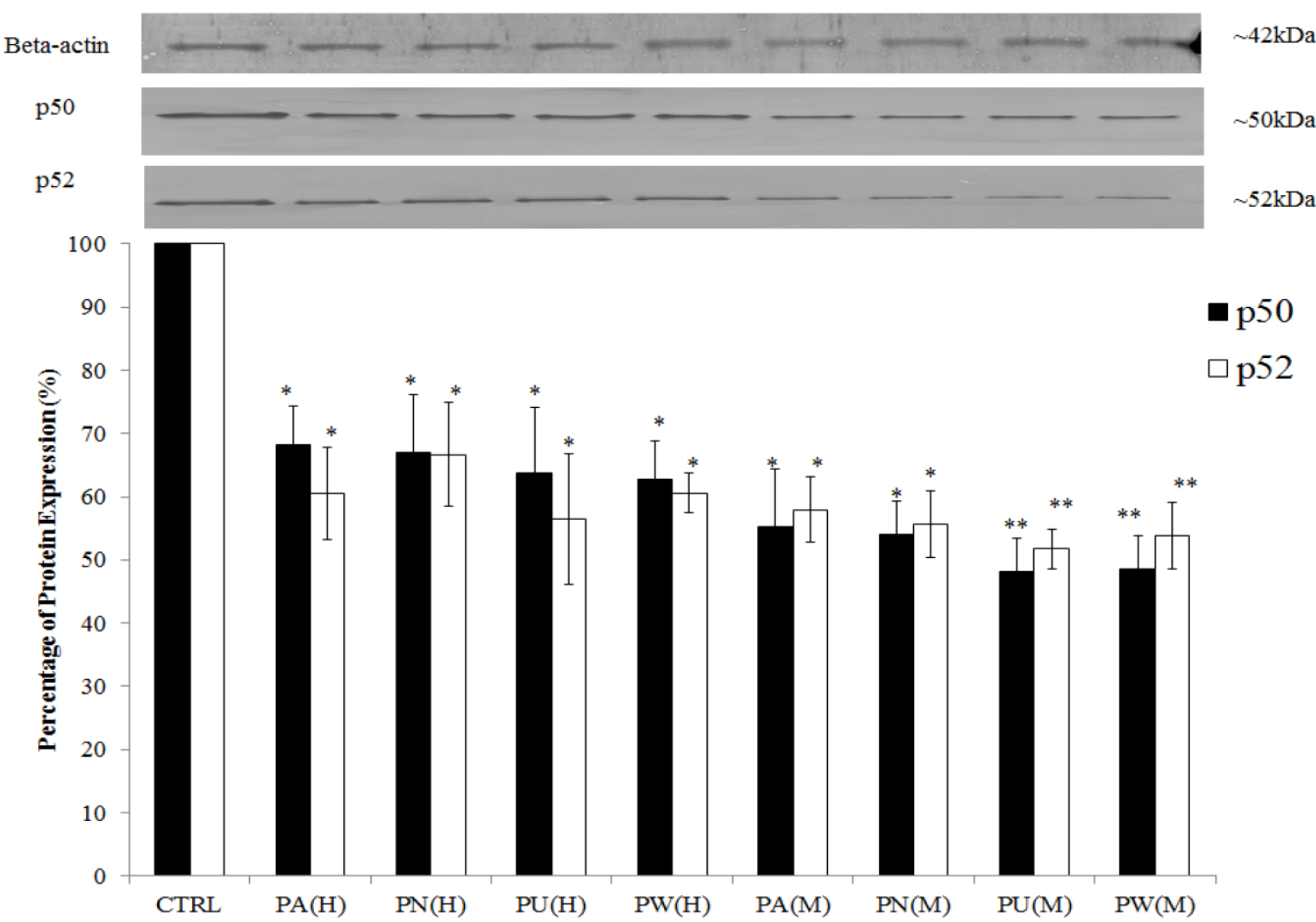

Figure 5. Inhibition of NFKB pathway in MeWo cells by Phyllanthus extracts. The expressions of $\mathrm{p} 50$ and p52 proteins were significantly down-regulated. Bars show the mean percentage \pm SEM. $* P<0.05$ and $* * P<0.01$ vs control. 
pI 3NL

pI $11 \mathrm{NL}$
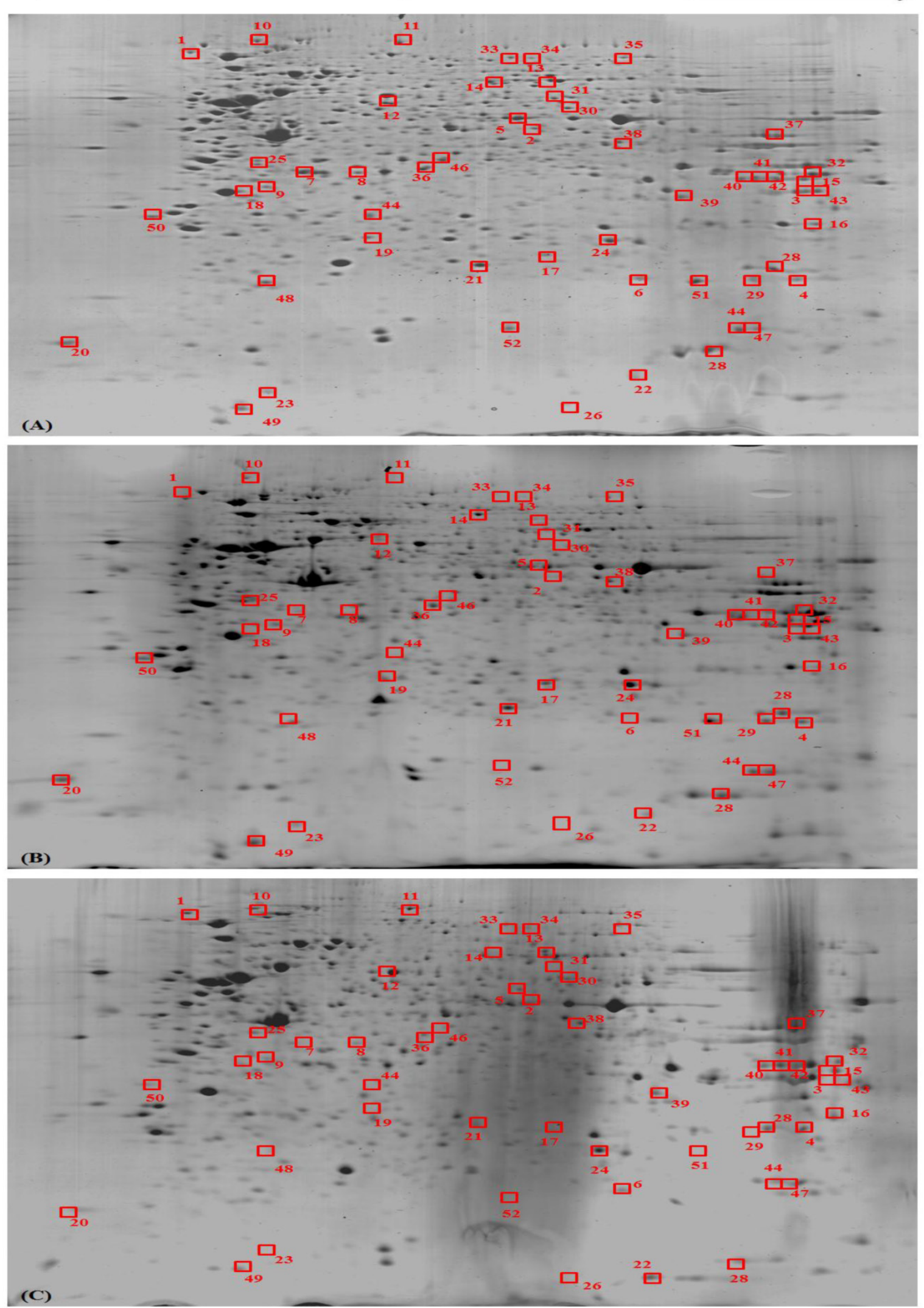

Figure 6. Proteomic profiling of the differentially expressed proteins in Phyllanthus extracts-treated MeWo cells. The differentially expressed proteins in (A) untreated, (B) aqueous- and (C) methanolic-treated of MeWo cells. 
Table 2: Fold changes of differential expressed proteins in aqueous- and methanolic-treated MeWo cells. Symbols“+” indicate up-regulation, and "-" indicate down-regulation. PA: P.amarus; PN: P.niruri; PU: P.urinaria and PW: P.watsonii.

\begin{tabular}{|c|c|c|c|c|c|c|c|c|c|c|}
\hline \multirow[t]{2}{*}{ No } & \multirow{2}{*}{$\begin{array}{l}\text { UniProtKB/Swiss-Prot } \\
\text { (Accession number) }\end{array}$} & \multirow[t]{2}{*}{ Protein } & \multicolumn{8}{|c|}{ Phyllanthus } \\
\hline & & & $\mathrm{PA}(\mathrm{H})$ & $\mathrm{PN}(\mathrm{H})$ & PU(H) & $\mathrm{PW}(\mathrm{H})$ & PA(M) & $\mathrm{PN}(\mathrm{M})$ & PU(M) & $\mathrm{PW}(\mathrm{M})$ \\
\hline I & \multicolumn{10}{|c|}{ Cell Adhesion, Migration, Invasion and Metastasis and Angiogenesis } \\
\hline 1 & P98172 & Ephrin-B1 & -1.46 & -1.47 & -1.53 & -1.48 & -1.59 & -1.58 & -1.57 & -1.65 \\
\hline 2 & P61163 & Alpha-centractin & -1.42 & -1.33 & -1.57 & -1.45 & -1.58 & -1.75 & -1.58 & -1.74 \\
\hline 3 & Q13895 & Bystin & -1.43 & -1.57 & -1.34 & -1.45 & -1.46 & -1.59 & -1.48 & -1.65 \\
\hline 4 & P13646 & Keratin, type I cytoskeletal 13 & 1.42 & 1.47 & 1.46 & 1.57 & 1.74 & 1.58 & 1.57 & 1.64 \\
\hline 5 & P08670 & Vimentin & -1.73 & -1.92 & -1.72 & -2.01 & -1.85 & -1.73 & -1.72 & -1.92 \\
\hline 6 & P04179 & $\begin{array}{l}\text { Superoxide dismutase [Mn], mito- } \\
\text { chondrial }\end{array}$ & -1.29 & -1.54 & -1.57 & -1.39 & -1.58 & -1.85 & -1.65 & -1.48 \\
\hline 7 & P07437 & Tubulin beta chain & -1.42 & -1.48 & -1.67 & -1.97 & -1.57 & -1.58 & -1.59 & -1.54 \\
\hline 8 & P47755 & $\begin{array}{l}\text { F-actin-capping protein subunit } \\
\text { alpha-2 }\end{array}$ & -1.34 & -1.33 & -1.63 & -1.58 & -1.68 & -1.58 & -1.53 & -1.63 \\
\hline 9 & Q8TEW0 & Partitioning defective 3 homolog & -1.32 & -1.49 & -1.32 & -1.68 & -1.50 & -1.56 & -1.68 & -1.58 \\
\hline II & \multicolumn{10}{|c|}{ Proliferation, Cell Cycle, and Apoptosis } \\
\hline 10 & P68400 & Casein kinase II subunit alpha & -2.28 & -1.97 & -1.83 & -2.08 & -2.18 & -2.08 & -1.95 & -2.07 \\
\hline 11 & P50583 & $\begin{array}{l}\text { Bis(5'-nucleosyl)-tetraphosphatase } \\
\text { [asymmetrical] }\end{array}$ & -1.47 & -1.53 & -1.48 & -1.37 & -1.58 & -1.74 & -1.63 & -1.75 \\
\hline 12 & O60220 & $\begin{array}{l}\text { Mitochondrial import inner mem- } \\
\text { brane translocase subunit Tim } 8\end{array}$ & -1.56 & -1.35 & -1.64 & -1.62 & -1.63 & -1.65 & -1.68 & -1.58 \\
\hline 13 & Q9BQ83 & $\begin{array}{l}\text { Structure-specific endonuclease } \\
\text { subunit SLX1 }\end{array}$ & -1.37 & -1.49 & -1.57 & -1.48 & -1.93 & -1.57 & -1.74 & -1.63 \\
\hline 14 & Q6Q0C0 & E3 ubiquitin-protein ligase TRAF7 & 1.48 & 1.57 & 1.65 & 1.57 & 1.45 & 1.78 & -1.69 & -1.549 \\
\hline 15 & P0CJ76 & Humanin-like protein 9 & -1.56 & -1.68 & -1.58 & -1.58 & -1.62 & 1.67 & 1.73 & 1.78 \\
\hline 16 & P17931 & Galectin-3 & -1.58 & -1.75 & -1.63 & -1.69 & -1.68 & -1.68 & -1.64 & -1.78 \\
\hline 17 & P31943 & $\begin{array}{l}\text { Heterogeneous nuclear ribonucleo- } \\
\text { protein H }\end{array}$ & -1.49 & -1.57 & -1.34 & -1.63 & -1.56 & -1.68 & -1.58 & -1.84 \\
\hline 18 & P08758 & Annexin A5 & -1.42 & -1.57 & -1.73 & -1.57 & -1.57 & -1.47 & -1.59 & -1.47 \\
\hline 19 & Q969E4 & $\begin{array}{l}\text { Transcription elongation factor A } \\
\text { protein-like } 3\end{array}$ & -1.32 & -1.47 & -1.57 & -1.74 & -1.62 & -1.48 & -1.68 & -1.57 \\
\hline 20 & Q9H930 & $\begin{array}{l}\text { Nuclear body protein SP140-like } \\
\text { protein }\end{array}$ & -1.32 & -1.38 & -1.55 & -1.57 & -1.58 & -1.58 & -1.57 & -1.58 \\
\hline 21 & P27348 & 14-3-3 protein theta & -1.42 & -1.47 & -1.29 & -1.58 & -1.57 & -1.67 & -1.45 & -1.34 \\
\hline 22 & P62937 & Peptidyl-prolyl cis-trans isomerase A & -1.54 & -1.23 & -1.47 & -1.54 & -1.58 & -1.62 & -1.57 & -1.46 \\
\hline 23 & Q14929 & Zinc finger protein 169 & -1.69 & -1.57 & -1.33 & -1.84 & -1.75 & -1.55 & -1.47 & -1.56 \\
\hline 24 & O75791 & GRB2-related adapter protein & -1.59 & -1.43 & -1.4 & -1.83 & -1.56 & -1.48 & -1.53 & -1.28 \\
\hline 25 & O00165 & HCLS1-associated protein X-1 & -1.69 & -1.72 & -1.97 & -1.66 & -1.84 & -1.86 & -1.67 & -1.78 \\
\hline 26 & O95243 & $\begin{array}{l}\text { Methyl-CpG-binding domain pro- } \\
\text { tein } 4\end{array}$ & -1.49 & -1.63 & -1.56 & -1.57 & -1.66 & -1.54 & -1.63 & -1.64 \\
\hline 27 & P78417 & Glutathione transferase omega - 1 & -1.45 & -1.53 & -1.46 & -1.57 & -1.64 & -1.53 & -1.48 & -1.58 \\
\hline 28 & Q06830 & Peroxiredoxin-1 & -1.45 & -1.42 & -1.46 & -1.47 & -1.64 & -1.74 & -1.53 & -1.48 \\
\hline 29 & P50453 & Serpin B9 & -1.32 & -1.31 & -1.53 & -1.56 & -1.57 & -1.45 & -1.55 & -1.63 \\
\hline 30 & Q8ND25 & E3 ubiquitin-protein ligase ZNRF1 & -1.48 & -1.64 & -1.67 & -1.57 & -1.56 & -1.46 & -1.53 & -1.58 \\
\hline 31 & Q06210 & E3 ubiquitin-protein ligase ARIH2 & -1.48 & -1.58 & -1.64 & -1.6 & -1.57 & -1.65 & -1.45 & -1.64 \\
\hline 32 & Q9Y4L5 & E3 ubiquitin-protein ligase RNF115 & -1.56 & -1.43 & -1.66 & -1.73 & -1.69 & -1.58 & -1.58 & -1.56 \\
\hline III & \multicolumn{10}{|c|}{ Glycogenesis and glycolysis } \\
\hline 33 & Q969E3 & $\begin{array}{l}\text { Glucosamine--fructose-6-phosphate } \\
\text { aminotransferase [isomerizing] } 2\end{array}$ & -1.57 & -1.58 & -1.58 & -1.53 & -1.65 & -1.73 & 1.67 & -1.48 \\
\hline 34 & P00558 & $\begin{array}{l}\text { Protein phosphatase } 1 \text { regulatory } \\
\text { subunit } 3 \mathrm{D}\end{array}$ & -1.33 & -1.58 & -1.53 & -1.64 & -1.56 & -1.37 & -1.57 & -1.74 \\
\hline 35 & P06733 & Alpha-enolase & -1.42 & -1.57 & -1.74 & -1.73 & -1.58 & -1.57 & -1.65 & -1.69 \\
\hline 36 & P04406 & Pyruvate kinase isozymes M1/M2 & -1.45 & -1.67 & -1.47 & -1.63 & -1.78 & -1.36 & -1.36 & -1.75 \\
\hline 37 & P04075 & Phosphoglycerate kinase 1 & -1.57 & -1.58 & -1.61 & -1.64 & -1.48 & -1.53 & -1.52 & -1.58 \\
\hline IV & \multicolumn{10}{|c|}{ Protein Synthesis and Energy Metabolism } \\
\hline 38 & P17174 & $\begin{array}{l}\text { Aspartate aminotransferase, cyto- } \\
\text { plasmic }\end{array}$ & -1.26 & -1.67 & -1.68 & -1.56 & -1.57 & -1.58 & -1.53 & -1.58 \\
\hline 39 & Q9UBC9 & Small proline-rich protein 3 & -1.63 & -1.75 & -1.74 & -1.56 & -1.67 & -1.68 & -1.73 & -1.57 \\
\hline 40 & P41247 & $\begin{array}{l}\text { Patatin-like phospholipase do- } \\
\text { main-containing protein } 4\end{array}$ & -1.63 & -1.32 & -1.49 & -1.66 & -1.53 & -1.53 & -1.58 & -1.64 \\
\hline 41 & Q9HBU6 & Ethanolamine kinase 1 & -1.39 & -1.75 & -1.57 & -1.83 & -1.48 & -1.75 & -1.68 & -1.74 \\
\hline 42 & P62195 & $26 S$ protease regulatory subunit 8 & -1.53 & -1.64 & -1.57 & -1.74 & -1.75 & -1.56 & -1.64 & -1.54 \\
\hline 43 & Q5VTE0 & Putative elongation factor & -1.48 & -1.64 & -1.64 & -1.57 & -1.57 & -1.64 & -1.58 & -1.85 \\
\hline
\end{tabular}




\begin{tabular}{|c|c|c|c|c|c|c|c|c|c|c|}
\hline \multirow{2}{*}{ No } & \multirow{2}{*}{$\begin{array}{l}\text { UniProtKB/Swiss-Prot } \\
\text { (Accession number) }\end{array}$} & \multirow{2}{*}{ Protein } & \multicolumn{8}{|c|}{ Phyllanthus } \\
\hline & & & $\overline{\mathrm{PA}(\mathrm{H})}$ & $\mathrm{PN}(\mathrm{H})$ & $\mathrm{PU}(\mathrm{H})$ & $\mathrm{PW}(\mathrm{H})$ & $\mathrm{PA}(\mathrm{M})$ & $\mathrm{PN}(\mathrm{M})$ & $\mathrm{PU}(\mathrm{M})$ & $\mathrm{PW}(\mathrm{M})$ \\
\hline & & 1-alpha-like 3 & & & & & & & & \\
\hline 44 & Q5TGZ0 & $\begin{array}{l}\text { Mitochondrial inner membrane } \\
\text { organizing system protein } 1\end{array}$ & -1.53 & -1.63 & -1.74 & -1.56 & -1.67 & -1.68 & -1.64 & -1.75 \\
\hline 45 & P07339 & Cathepsin D & -1.54 & -1.54 & -1.65 & -1.46 & -1.68 & -1.68 & -1.47 & -1.58 \\
\hline 46 & Q9Y587 & AP-4 complex subunit sigma- 1 & -1.33 & -1.57 & -1.56 & -1.36 & -1.68 & -1.74 & -1.58 & -1.67 \\
\hline 47 & P00568 & Adenylate kinase & -1.58 & -1.39 & -1.53 & -1.57 & -1.56 & -1.63 & -1.68 & -1.58 \\
\hline 48 & P80294 & Metallothionein- $1 \mathrm{H}$ & -1.29 & -1.74 & -1.73 & -1.45 & -1.59 & -1.58 & -1.76 & -1.68 \\
\hline 49 & Q76KX8 & Zinc finger protein 534 & -1.59 & -1.46 & -1.57 & -1.64 & -1.54 & -1.63 & -1.58 & -1.58 \\
\hline 50 & Q9Y6H3 & $\begin{array}{l}\text { Mitochondrial inner membrane } \\
\text { protease ATP23 homolog }\end{array}$ & -1.59 & -1.56 & -1.57 & -1.67 & -1.68 & -1.67 & -1.68 & -1.63 \\
\hline 51 & Q8WVM8 & $\begin{array}{l}\text { Sec1 family domain-containing pro- } \\
\text { tein } 1\end{array}$ & -1.44 & -1.56 & -1.64 & -1.54 & -1.76 & -1.65 & -1.75 & -1.64 \\
\hline 52 & Q9NVH6 & $\begin{array}{l}\text { Trimethyllysine dioxygenase, mito- } \\
\text { chondrial }\end{array}$ & -1.58 & -1.48 & -1.58 & -1.54 & -1.79 & -1.68 & -1.53 & -1.66 \\
\hline
\end{tabular}

\section{Discussion}

Understanding cell signalling in cancer is of paramount importance and may provide potential targets for anticancer agents to induce apoptosis and/or inhibitions tumour metastasis and angiogenesis. Previously, we showed that Phyllanthus was capable of exhibiting selective cytotoxicity on melanoma cancer cells and apoptosis induction [19], was most likely attributed to the mixture bioactive compounds within the plant.

Bcl-2-family proteins play an important role in cell death regulation including apoptosis, necrosis and autophagy [26]. Overexpression of the anti-apoptotic proteins (e.g. Bcl-2) and suppression of pro-apoptotic proteins (e.g. Bax) have been demonstrated to inhibit cell death leading to formation of cancer [26]. In our study, the expression of Bax proteins was greatly up-regulated accompanied by down-regulation of Bcl-2 expression in Phyllanthus-treated MeWo cells (Figure 2). The highly expressed Bax protein could induce changes in mitochondrial outer membrane permeabilization (MOMP), causing the release of cytochrome $c$. This release will then induce caspase activation $[27,28]$ as detected in our previous report [19] and also inhibit the inhibitors of apoptosis (IAP) (e.g. SMAC and OMI/Htra2) [28, 29]. Finally, this will leads to apoptosis induction in MeWo cells. In addition, another apoptotic protein, p53 was also found to be up-regulated in treated MeWo cells which could induce apoptosis through its transcription activity to produce pro-apoptotic proteins (e.g. Bid, Bax, Nova and PUMA) which in turn leads to cytochrome $c$ release and activation of capases [30,31].

Ras gene is frequently found high expressed in human cancers [32] whereby it triggers various other intracellular signalling cascades to regulate genes-driven malignancy of cancer including prolif- eration, evasion of apoptosis, metastasis and angiogenesis [33]. When MeWo cells were treated with Phyllanthus, a down-regulation of Ras proteins was observed and this will eventually lead to suppression of its downstream targets; Raf and Akt as observed (Figure 3).

In melanoma, active ERK1/2 molecule has been shown to activate RSK and Elk molecules; subsequently activating c-Jun and c-Fos proteins. The combination of c-Jun and c-Fos will form activator protein 1 (AP-1), a transcription factor that translocates into nucleus and regulates cell survival genes [33]. In addition, p38 MAPK also enhances AP-1 formation by producing c-Fos through activation on Elk protein [5]. However, in Phyllanthus-treated MeWo cells, all the above-mentioned MAPK intracellular signalling molecules were noted to be down-regulated (Figure $3)$.

Tumour necrosis factor-alpha (TNF-a) is a cytokine capable of activating multiple downstream signalling pathways, including caspases, ІкB kinase (IKK) and JNK [34, 35]. TNF-a does not usually induce apoptosis unless NFKB has been inactivated [35]. During TNF-a induced apoptosis, caspases will be activated, and IKK will be inactivated causing NFKB to bind with its inhibitor; subsequently inhibiting the ability to regulate genes including inhibitors of apoptosis (IAPs) family.

The inhibition of NFkB was observed in Phyllanthus-treated MeWo cells by measurements of NFkB-1 (p50) and NFkB -2 (p52). Furthermore, we believed that the down-regulation of NFkB pathway in treated MeWo cells can inhibit proliferation, metastasis and angiogenesis by suppressing the MMP, VEGF, and IL-8, and anti-apoptotic proteins (bcl-xl, cIAP) as well as inducing programmed cell death in MeWo cells [37, 42].

The PI3K/Akt pathway is found highly expressed in advanced melanoma and inhibits apoptosis 
[43-45]. However, the suppression of Akt protein in treated MeWo could induce apoptosis by the activation pro-apoptotic factors (Bad, GSK3ß, procaspase-9 and TRAIL/APO-2L (TNF-Related Apoptosis-Inducing Ligand) [46, 47] and inhibition of anti-apoptotic factors (cyclic AMP response element-binding protein (CREB) and the IKB kinase (IKK) [47]. The up-regulation of phosphorylated GSK3 $\beta$ was detected in treated MeWo cells can further degrade c-myc as was observed; possibly halting tumour growth with induction of S-phase arrest as we report previously [19]. In addition, the cell cycle arrest at S-phase could be due to the activation of p53 as p21 is a major target for transactivation by p53 [51] which will then induce cell cycle arrest at S-phase through two mechanisms; (1) interaction of p21 with the proliferating cell nuclear antigen (PCNA) [52] and/or (2) p21 directly inhibiting the activity of cyclin E/CDK2 complexes [53].

According to Warburg effect, the microenvironment surrounding a solid tumour is an anaerobic/ hypoxia state. This will lead cancer cells to up-regulate the expression of intracellular signalling molecules and enzymes that involved anaerobic glycolytic pathway [54-56]. Hypoxia-inducible factor (HIF) is an important protein activated upon hypoxic condition or low oxygen level [13]. The target genes of HIF are involved in angiogenesis (e.e VEGF), cell survival (e.g. IGF-1) and metastasis (e.g. LOX, PAI-1) and all these process can drive tumour progression [14]. In our study, Phyllanthus extracts were noted to inhibit the glycolytic pathway and ATP production in melanoma cells by down-regulating the HIF-1a protein and vascular endothelial growth factor (VEGF) (Figure 5). In addition, several of glycolytic enzymes were found to be down-regulated in MeWo cells after treatment with Phyllanthus extracts such as glucosamine--fructose-6-phosphate aminotransferase, protein phosphatase 1 regulatory subunit 3D, alpha-enolase, pyruvate kinase isozymes M1/M2 and phosphoglycerate kinase 1 . The down-regulation in PI3K/Akt and Ras/MAPK pathways in treated MeWo cells are believed to be involved in the inhibition of hypoxia pathway [14].

The epithelial-mesenchymal transition (EMT) is a cellular process that allows immotile epithelial cells to become motile mesenchymal cells, promoting carcinoma invasion and metastasis as well as resistance to apoptosis [57]. Several signalling networks including Ras/MAPK-, PI3K/Akt-, Wnt- and NFKB-dependent pathways in EMT were found to be down regulated in treated MeWo cells, and thus were believed to inhibit metastasis of melanoma [58]. The inhibition on melanoma metastasis was further imposed with the up-regulation of type I cytoskeletal 13 keratin and concurrent down-regulation of vimentin in MeWo cells after treatment with Phyllanthus. Despite the exact mechanism of up-regulation of keratin during EMT being unclear but its down-regulation in treated cells can restrict the motility of cells, thus halting metastasis [59,60]. Vimentin also plays an important role in cell survival by stabilizing the ERK protein and governing its translocation into the nucleus [61] and by preventing assembly of Raf-14-3-3 complex enabling Ras protein to be continuously expressed [62]. Therefore, the down regulation of vimentin could induce apoptosis via suppression on ERK- and Ras-dependent survival pathways in MeWo cells.

Following the treatment of Phyllanthus, many tightly regulated proteins were found to be altered in MeWo cells. Of these, two proteins, HCLS1-associated protein X-1 (HAX1) and casein kinase II subunit alpha. HAX-1 interacts with HS1 and a-subunit of Ga13 heterotrimeric $G$ protein for cell migration $[63,64]$ and is highly expressed in hypoxic tumor progression [65, 66]. Protein kinase casein kinase II (CK2) is a highly conserved protein serine/threonine kinase and is found highly expressed in cancers [67-70]. CK2 can be anti-apoptotic via (1) inhibition on Max, a transcriptional partner of the c-myc, from caspase-mediated degradation [71], (2) activation of Bid, a pro-apoptotic protein [72], and (3) confer protection from Fas- and drug-triggered apoptosis [72, 73]. Therefore, down-regulation of CK2 in treated MeWo cells could elicit apoptosis induction and could increase the susceptibility of MeWo cells to apoptotic inducer chemotherapeutic agents [74-76].

Mitochondrion is involved in protein synthesis and energy metabolism for cancer cell survival, transformation, invasion, and metastasis. The alteration in mitochondrial integrity and ubiquitination components such as E3 ubiquitin-protein ligase ARIH2 and RNF115, aspartate aminotransferase, 26S protease regulatory subunit 8 , putative elongation factor 1-alpha-like 3, mitochondrial inner membrane organizing system protein 1 (MINOS), zinc finger protein, Sec1 and trimethyllysine dioxygenase, by Phyllanthus in MeWo cells could inhibit ATP production and stability of proteins, therefore halting cancer growth. In addition, disruption on mitochondria stability could elicit apoptosis in MeWo by releasing its components, cytochrome $c$ [36].

Based on the findings, we proposed a schematic presentation of the possible mechanism behind the anti-cancer activity of Phyllanthus extracts in MeWo cells (Figure 7). In conclusion, this study revealed a comprehensive perspective of the possible mechanism behind the anti-cancer activity of Phyllanthus extracts by inspection of their regulation in multiple 
signalling pathways and protein-protein interaction in melanoma MeWo cells. In addition, the identified differentially expressed proteins could become potential targets for new anticancer agent development.

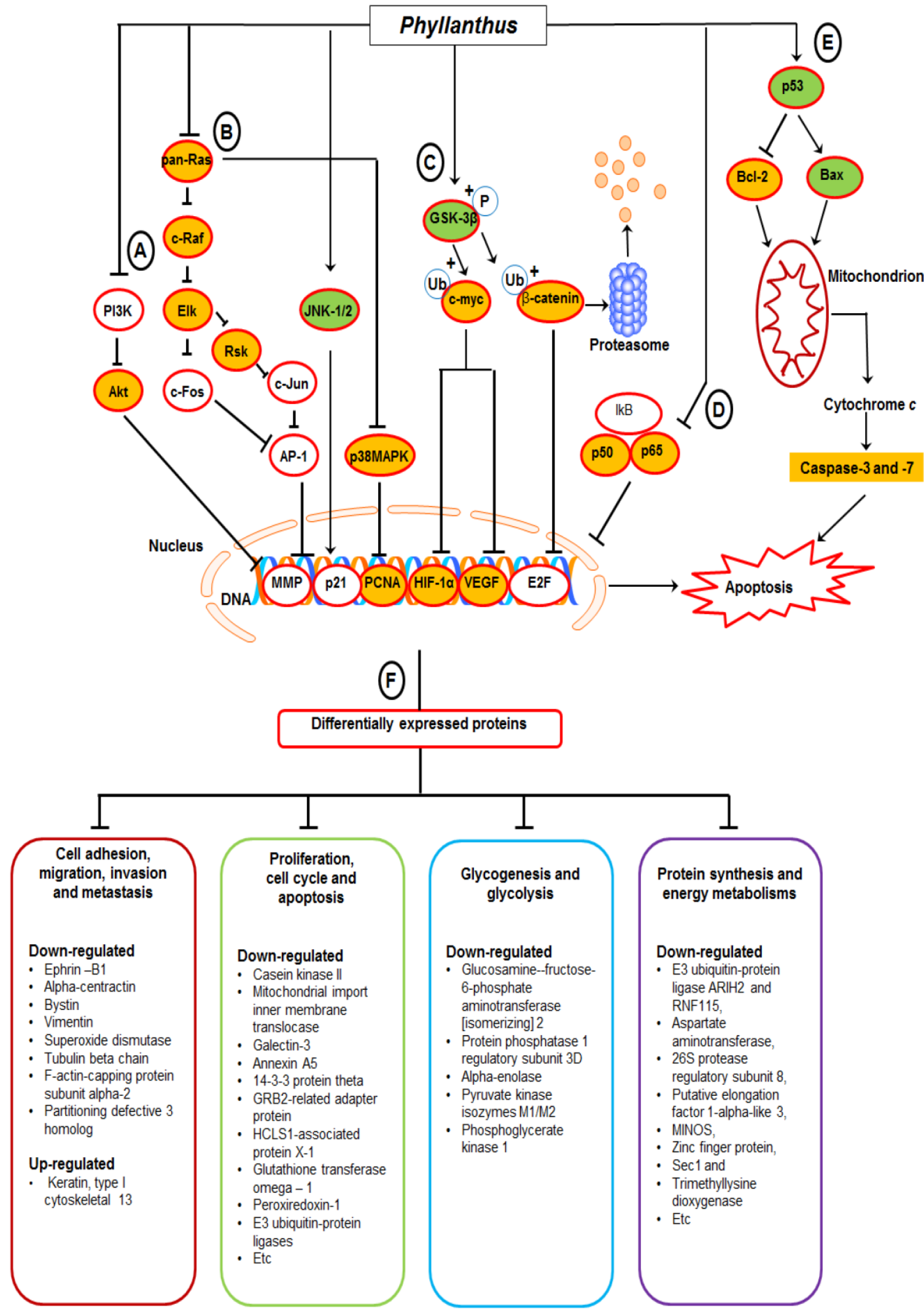

Figure 7. A proposed schematic diagram of (A) PI3K/Akt, (B) MAPKs, (C) Myc/Max and Hypoxia, (D) NFKB, and (E) p53 apoptosis signalling pathways as well as (F) multiple proteins regulations in Phyllanthus-treated MeWo cells. See the text for discussion. 


\section{Acknowledgments}

This study was supported by Postgraduate Research Grant, University of Malaya (PV053/2011B), University of Malaya Research Grant (UMRG) (RG391-11HTM) and Malaysian Agricultural and Research Development Institute (MARDI) (53-02-03-1002).

\section{Abbreviations}

NFkB, Nuclear Factor-kappa B; MAPK, Mitogen-Activated Protein Kinases; ERK, Extracellular signal-regulated kinases; JNK, c-Jun N-terminal kinase; RSK, Ribosomal s6 kinase; Elk1, E twenty-six (ETS)-like transcription factor 1; HIF-1a, Hypoxia-inducible factor 1alpha; VEGF, vascular endothelial growth factor; GSK3 $\beta$, Glycogen synthase kinase-3 beta; MMP, matrix metalloproteinase; PI3K, Phosphatidylinositide 3-kinase.

\section{Competing Interests}

The authors have declared that no competing interest exists.

\section{References}

1. Miller AJ, Mihm Jr MC. Melanoma. New England Journal of Medicine. 2006; 355: 51-65.

2. Tsao H, Sober AJ. Melanoma treatment update. Dermatologic clinics. 2005; 23 : 323.

3. Anagnostopoulos K, Tentes I, Kortsaris A. Cell signaling in cancer. Journal of BU ON: official journal of the Balkan Union of Oncology. 2008; 13: 17.

4. Martin GS. Cell signaling and cancer. Cancer cell. 2003; 4: 167-74.

5. Dhillon A, Hagan S, Rath O, Kolch W. MAP kinase signalling pathways in cancer. Oncogene. 2007; 26: 3279-90.

6. Oh AS, Lorant LA, Holloway JN, Miller DL, Kern FG, El-Ashry D. Hyperactivation of MAPK induces loss of ERa expression in breast cancer cells. Molecular Endocrinology. 2001; 15: 1344-59.

7. Barault L, Veyrie N, Jooste V, Lecorre D, Chapusot C, Ferraz JM, et al. Mutations in the RAS-MAPK, PI (3) K (phosphatidylinositol-3-OH kinase) signaling network correlate with poor survival in a population-based series of colon cancers. International journal of cancer. 2008; 122: 2255-9.

8. Fecher LA, Amaravadi RK, Flaherty KT. The MAPK pathway in melanoma. Current opinion in oncology. 2008; 20: 183-9

9. Chen KH, Weng MS, Lin JK. Tangeretin suppresses IL-1 $\beta$-induced cyclooxygenase (COX)-2 expression through inhibition of p38 MAPK, JNK, and AKT activation in human lung carcinoma cells. Biochemical pharmacology. 2007; 73: 215-27.

10. Polakis P. The many ways of Wnt in cancer. Current Opinion in Genetics \& Development. 2007; 17: 45-51.

11. McNulty SE, Tohidian NB, Meyskens FL. RelA, p50 and inhibitor of kappa B alpha are elevated in human metastatic melanoma cells and respond aberrantly to ultraviolet light B. Pigment Cell Research. 2001; 14: 456-65.

12. Dhawan $\mathrm{P}$, Singh $\mathrm{AB}$, Ellis $\mathrm{DL}$, Richmond $\mathrm{A}$. Constitutive activation of $\mathrm{Akt} /$ protein kinase $\mathrm{B}$ in melanoma leads to up-regulation of nuclear factor- $\mathrm{kB}$ and tumor progression. Cancer research. 2002; 62: 7335-42.

13. Ziello JE, Jovin IS, Huang Y. Hypoxia-Inducible Factor (HIF)-1 regulatory pathway and its potential for therapeutic intervention in malignancy and ischemia. The Yale Journal of Biology and Medicine. 2007; 80: 51.

14. Poon E, Harris AL, Ashcroft M. Targeting the hypoxia-inducible factor (HIF) pathway in cancer. Expert Reviews in Molecular Medicine. 2009; 11

15. Lam WY, Leung KT, Law PTW, Lee SMY, Chan HLY, Fung KP, et al. Antiviral effect of Phyllanthus nanus ethanolic extract against hepatitis B virus (HBV) by expression microarray analysis. Journal of cellular biochemistry. 2006; 97: 795-812.

16. Doughari J, Sunday D. Antibacterial Activity of Phyllanthus muellerianus. Pharmaceutical biology. 2008; 46: 400-5.

17. Ahmed B, Al-Howiriny A, Mathew R. Anti-hepatotoxic activity of Phyllanthus fraternus. Pharmazie. 2002; 57: 855-6.

18. Huang ST, Pang JHS, Yang RC. Anti-cancer effects of Phyllanthus urinaria and relevant mechanisms. Chang Gung Med J. 2010; 33.
19. Tang YQ, Jaganath IB, Sekaran SD. Phyllanthus spp. induces selective growth inhibition of PC-3 and MeWo human cancer cells through modulation of cell cycle and induction of apoptosis. PLoS One. 2010; 5: e12644. doi:10.1371/journal.pone.0012644.

20. Hanahan D, Weinberg RA. Hallmarks of cancer: the next generation. Cell. 2011; 144: 646-74.

21. Kasibhatla S, Tseng B. Why target apoptosis in cancer treatment? Molecular cancer therapeutics. 2003; 2: 573-80.

22. Lowe SW, Lin AW. Apoptosis in cancer. Carcinogenesis. 2000; 21: 485-95.

23. Ho HH, Chang CS, Ho WC, Liao SY, Wu CH, Wang CJ. Anti-metastasis effects of gallic acid on gastric cancer cells involves inhibition of NF-KB activity and downregulation of PI3K/AKT/small GTPase signals. Food and Chemical Toxicology. 2010; 48: 2508-16.

24. Huang ST, Yang RC, Pang JHS. Aqueous extract of Phyllanthus urinaria induces apoptosis in human cancer cells. The American Journal of Chinese Medicine. 2004; 32: 175-83.

25. Sun J, Hai Liu R. Cranberry phytochemical extracts induce cell cycle arrest and apoptosis in human MCF-7 breast cancer cells. Cancer letters. 2006; 241: 124-34.

26. Gross A, McDonnell JM, Korsmeyer SJ. BCL-2 family members and the mitochondria in apoptosis. Genes \& Development. 1999; 13: 1899-911.

27. Coultas L, Strasser A. The role of the Bcl-2 protein family in cancer. Seminars in cancer biology: Elsevier; 2003. :115-23.

28. Yip K, Reed J. Bcl-2 family proteins and cancer. Oncogene. 2008; 27: 6398-406.

29. Chang HY, Yang X. Proteases for cell suicide: functions and regulation of caspases. Microbiology and molecular biology reviews. 2000; 64: 821-46.

30. Fridman JS, Lowe SW. Control of apoptosis by p53. Oncogene. 2003; 22: 9030-40.

31. Schuler M, Bossy-Wetzel E, Goldstein JC, Fitzgerald P, Green DR. p53 induces apoptosis by caspase activation through mitochondrial cytochrome $\mathrm{c}$ release. Journal of Biological Chemistry. 2000; 275: 7337-42.

32. Bos JL. Ras oncogenes in human cancer: a review. Cancer research. 1989; 49: 4682-9.

33. Roberts P, Der C. Targeting the Raf-MEK-ERK mitogen-activated protein kinase cascade for the treatment of cancer. Oncogene. 2007; 26: 3291-310.

34. Lin A. Activation of the JNK signaling pathway: breaking the brake on apoptosis. Bioessays. 2002; 25: 17-24

35. Karin M, Lin A. NF-kappaB at the crossroads of life and death. Nature immunology. 2002; 3: 221-7.

36. Debatin KM. Apoptosis pathways in cancer and cancer therapy. Cancer Immunology, Immunotherapy. 2004; 53: 153-9.

37. Aggarwal BB. Nuclear factor-kB: the enemy within. Cancer cell. 2004; 6: 203-8.

38. Baldwin Jr AS. The NF- $\mathrm{BB}$ and IКB proteins: new discoveries and insights. Annual review of immunology. 1996; 14: 649-81.

39. Wang CY, Mayo MW, Korneluk RG, Goeddel DV, Baldwin Jr AS. NF-kB antiapoptosis: induction of TRAF1 and TRAF2 and c-IAP1 and c-IAP2 to suppress caspase-8 activation. Science. 1998; 281: 1680-3.

40. Farina AR, Cappabianca L, DeSantis G, Ianni ND, Ruggeri P, Ragone M, et al. Thioredoxin stimulates MMP-9 expression, de-regulates the MMP-9/TIMP-1 equilibrium and promotes MMP-9 dependent invasion in human MDA-MB-231 breast cancer cells. FEBS letters. 2011; 585: 3328-36.

41. Bond $\mathrm{M}$, Chase $\mathrm{AJ}$, Baker $\mathrm{AH}$, Newby AC. Inhibition of transcription factor NF-KB reduces matrix metalloproteinase- $1,-3$ and- 9 production by vascular smooth muscle cells. Cardiovascular research. 2001; 50: 556-65.

42. Shishodia S, Aggarwal BB. Guggulsterone inhibits NF-kB and IкBa kinase activation, suppresses expression of anti-apoptotic gene products, and enhances apoptosis. Journal of Biological Chemistry. 2004; 279: 47148-58.

43. Majewski N, Nogueira V, Bhaskar P, Coy PE, Skeen JE, Gottlob K, et al. Hexokinase-mitochondria interaction mediated by Akt is required to inhibit apoptosis in the presence or absence of Bax and Bak. Molecular cell. 2004; 16: 819-30.

44. Rathmell JC, Fox CJ, Plas DR, Hammerman PS, Cinalli RM, Thompson CB. Akt-directed glucose metabolism can prevent Bax conformation change and promote growth factor-independent survival. Molecular and cellular biology. 2003; 23: 7315-28.

45. Dai DL, Martinka M, Li G. Prognostic significance of activated Akt expression in melanoma: a clinicopathologic study of 292 cases. Journal of clinical oncology. 2005; 23: 1473-82.

46. Majumder PK, Sellers WR. Akt-regulated pathways in prostate cancer. Oncogene. 2005; 24: 7465-74.

47. Vara JÁF, Casado E, de Castro J, Cejas P, Belda-Iniesta C, González-Barón M. PI3K/Akt signalling pathway and cancer. Cancer Treatment Reviews. 2004; 30: $193-204$

48. Dang CV, O'Donnell KA, Zeller KI, Nguyen T, Osthus RC, Li F. The c-Myc target gene network. Seminars in cancer biology: Elsevier; 2006. :253-64.

49. Dominguez-Sola D, Ying CY, Grandori C, Ruggiero L, Chen B, Li M, et al. Non-transcriptional control of DNA replication by c-Myc. Nature. 2007; 448: 445-51.

50. Robinson K, Asawachaicharn N, Galloway DA, Grandori C. c-Myc accelerates S-phase and requires WRN to avoid replication stress. PLoS One. 2009; 4: e5951.

51. Radhakrishnan SK, Feliciano CS, Najmabadi F, Haegebarth A, Kandel ES, Tyner AL, et al. Constitutive expression of E2F-1 leads to p21-dependent cell cycle arrest in $S$ phase of the cell cycle. Oncogene. 2004; 23: 4173-6. 
52. Waga S, Hannon GJ, Beach D, Stillman B. The p21 inhibitor of cyclin-dependent kinases controls DNA replication by interaction with PCNA. Nature. 1994; 369: 574-8.

53. Shishodia S, Sethi G, Ahn KS, Aggarwal BB. Guggulsterone inhibits tumor cell proliferation, induces S-phase arrest, and promotes apoptosis through activation of c-Jun N-terminal kinase, suppression of Akt pathway, and downregulation of antiapoptotic gene products. Biochemical Pharmacology. 2007; 74: 118-30.

54. Warburg O. On the origin of cancer cells. Science. 1956; 123: 309-14.

55. Xu R, Pelicano H, Zhou Y, Carew JS, Feng L, Bhalla KN, et al. Inhibition of glycolysis in cancer cells: a novel strategy to overcome drug resistance associated with mitochondrial respiratory defect and hypoxia. Cancer Research. 2005; 65: 613-21.

56. Guppy M. The hypoxic core: a possible answer to the cancer paradox. Biochemical and Biophysical Research Communications. 2002; 299: 676-80.

57. Voulgari A, Pintzas A. Epithelial-mesenchymal transition in cancer metastasis: mechanisms, markers and strategies to overcome drug resistance in the clinic. Biochimica et Biophysica Acta (BBA)-Reviews on Cancer. 2009; 1796: 75-90.

58. Yilmaz M, Christofori G. EMT, the cytoskeleton, and cancer cell invasion. Cancer and Metastasis Reviews. 2009; 28: 15-33.

59. Stockinger A, Eger A, Wolf J, Beug H, Foisner R. E-cadherin regulates cell growth by modulating proliferation-dependent $\beta$-catenin transcriptional activity. The Journal of cell biology. 2001; 154: 1185-96.

60. Valdés F, Murillo MM, Valverde ÁM, Herrera B, Sánchez A, Benito M, et al. Transforming growth factor-beta activates both pro-apoptotic and survival signals in fetal rat hepatocytes. Experimental cell research. 2004; 292: 209-18.

61. Perlson E, Michaelevski I, Kowalsman N, Ben-Yaakov K, Shaked M, Seger R, et al. Vimentin binding to phosphorylated Erk sterically hinders enzymatic dephosphorylation of the kinase. Journal of Molecular Biology. 2006; 364: 938-44.

62. Tzivion G, Gupta VS, Kaplun L, Balan V. 14-3-3 proteins as potential oncogenes. Seminars in Cancer Biology: Elsevier; 2006. :203-13.

63. Suzuki Y, Demoliere C, Kitamura D, Takeshita H, Deuschle U, Watanabe T HAX-1, a novel intracellular protein, localized on mitochondria, directly associates with HS1, a substrate of Src family tyrosine kinases. The Journal of Immunology. 1997; 158: 2736-44.

64. Radhika V, Onesime D, Ha JH, Dhanasekaran N. Ga13 stimulates cell migration through cortactin-interacting protein Hax-1. Journal of Biological Chemistry. 2004; 279: 49406-13.

65. Ramsay AG, Keppler MD, Jazayeri M, Thomas GJ, Parsons M, Violette S, et al. HS1-associated protein X-1 regulates carcinoma cell migration and invasion via clathrin-mediated endocytosis of integrin av $\beta 6$. Cancer Research. 2007; 67: 5275-84.

66. Klein C, Grudzien M, Appaswamy G, Germeshausen M, Sandrock I, Schäffer AA, et al. HAX1 deficiency causes autosomal recessive severe congenital neutropenia (Kostmann disease). Nature Genetics. 2006; 39: 86-92.

67. Litchfield DW. Protein kinase CK2: structure, regulation and role in cellular decisions of life and death. Biochemical Journal. 2003;369: 1.

68. MÜNSTERMANN U, FRITZ G, SEITZ G, YIPING L, SCHNEIDER HR, ISSINGER OG. Casein kinase II is elevated in solid human tumours and rapidly proliferating non-neoplastic tissue. European Journal of Biochemistry. 2005; 189: 251-7.

69. Landesman-Bollag E, Romieu-Mourez R, Song DH, Sonenshein GE, Cardiff RD, Seldin DC. Protein kinase CK2 in mammary gland tumorigenesis. Oncogene. 2001; 20: 3247-57.

70. Faust RA, Niehans G, Gapany M, Hoistad D, Knapp D, Cherwitz D, et al. Subcellular immunolocalization of protein kinase CK2 in normal and carcinoma cells. The International Journal of Biochemistry \& Cell Biology. 1999; 31: 941-9.

71. Krippner-Heidenreich A, Talanian RV, Sekul R, Kraft R, Thole H, Ottleben H, et al. Targeting of the transcription factor Max during apoptosis: phosphorylation-regulated cleavage by caspase- 5 at an unusual glutamic acid residue in position P1. Biochemical Journal. 2001; 358: 705.

72. Desagher S, Osen-Sand A, Montessuit S, Magnenat E, Vilbois F, Hochmann A, et al. Phosphorylation of bid by casein kinases I and II regulates its cleavage by caspase 8. Molecular Cell. 2001; 8: 601-11.

73. Guo C, Yu S, Davis AT, Wang H, Green JE, Ahmed K. A potential role of nuclear matrix-associated protein kinase CK2 in protection against drug-induced apoptosis in cancer cells. Journal of Biological Chemistry. 2001; 276: 5992-9.

74. Ruzzene M, Penzo D, Pinna LA. Protein kinase CK2 inhibitor 4, 5, 6 , 7-tetrabromobenzotriazole (TBB) induces apoptosis and caspase-dependent degradation of haematopoietic lineage cell-specific protein 1 (HS1) in Jurkat cells. Biochemical Journal. 2002; 364: 41.

75. Ravi R, Bedi A. Sensitization of tumor cells to Apo2 ligand/TRAIL-induced apoptosis by inhibition of casein kinase II. Cancer Research. 2002; 62: 4180-5.

76. Ahmad KA, Wang G, Unger G, Slaton J, Ahmed K. Protein kinase CK2-a key suppressor of apoptosis. Advances in enzyme regulation. 2008; 48: 179. 